\title{
Interaction of polyamine on oxidative stress induced by exogenously applied hydrogen peroxide in Salvinia natans Linn
}

\section{Chiranjib Mandal', Nirmalya Ghosh', Malay Kumar Adak ${ }^{1 *}$, Narottam Dey²}

'Plant Physiology and Plant Molecular Biology Research Unit, Department of Botany, University of Kalyani, Kalyani, India.

${ }^{2}$ Department of Biotechnology, Visva-Bharati University, Shantiniketan, India.

*Corresponding author: mkadak09@gmail.com

Received: 13 January 2013; Accepted: 01 August 2013

ABSTRACT: A hydroponics experiment was carried out to study the role of hydrogen peroxide $\left(\mathrm{H}_{2} \mathrm{O}_{2}\right)$ through changes of oxidative stress and antioxidation activity in Salvinia natans Linn. $\mathrm{H}_{2} \mathrm{O}_{2}$ is an active oxygen species, widely generated in many biological systems, and mediates various physiological and biochemical processes in plants. In this study, we demonstrated that exogenous $\mathrm{H}_{2} \mathrm{O}_{2}$ causes the degradation of pigments and induces the oxidative stress and the antioxidation activity. These effects enhanced with increments of applied $\mathrm{H}_{2} \mathrm{O}_{2}$ concentration. Application of polyamine reduced the generation and the accumulation of $\mathrm{H}_{2} \mathrm{O}_{2}$ and modulated the enzyme activities.

KEYWORDS: Hydrogen peroxide, reactive oxygen species, antioxidative enzymes, polyamine, Salvinia natans.

ABBREVIATIONS: $\mathrm{H}_{2} \mathrm{O}_{2}$ : hydrogen peroxide; Put: putrescine; ROS: reactive oxygen species; DAB: 3,3-diaminobenzidine; TCA: tricholoroacetic acid; DTT: dithiothreitol; HEPES: 4-(2-hydroxyethyl)-1-piperazineethanesulfonic acid; GPX: guaiacol peroxidase; APX: ascorbate peroxidase; CAT: catalase; GR: glutathione reductase; SOD: superoxide dismutase; NBT: nitro-blue tetrazolium; GSH: reduced glutathione; GSSG: oxidized glutathione.

\section{INTRODUCTION}

Hydrogen peroxide $\left(\mathrm{H}_{2} \mathrm{O}_{2}\right)$ is a Reactive Oxygen Species (ROS), but not a free radical, which is two electron reduced product of a molecular oxygen. The generation of $\mathrm{H}_{2} \mathrm{O}_{2}$ in plant cells is present in a number of cellular metabolic pathways, including photosynthesis, photorespiration and other processes involving the electron transfer in cellular organelle. Under abiotic stress, ROS generation is almost mandatory (Ghosh et al. 2011). By comparing with superoxide $\left(\mathrm{O}_{2}{ }^{\bullet}\right)$, hydroxyl radical $(\bullet \mathrm{OH})$ and other ROS, $\mathrm{H}_{2} \mathrm{O}_{2}$ is the most stable compound (Cheeseman 2007). Within the cellular concentration, $\mathrm{H}_{2} \mathrm{O}_{2}$ behaves as a signaling molecule and it is used for the induction of gene expression, helpful for physiological process (Nathues et al. 2004). $\mathrm{H}_{2} \mathrm{O}_{2}$ becomes more dangerous when it reacts with some transition metals as $\mathrm{Fe}^{2+}$ and produces two molecules of $\mathrm{OH}^{-}$by Fenton reaction (Becana et al. 1998).

Abiotic stresses in different forms lead to the establishment of an over oxidation status of the tissue and thus result in oxidative stress. $\mathrm{H}_{2} \mathrm{O}_{2}$ itself being a ROS is duly generated by some oxidative reactions, which could be detrimental itself, and other subsequent product following lysis (Cheeseman 2007). $\mathrm{H}_{2} \mathrm{O}_{2}$ in subsequent reaction is converted into $\mathrm{OH}^{-}$, which is fatal to plants. In plant system, some of the moieties can interact with $\mathrm{H}_{2} \mathrm{O}_{2}$ and other ROS to moderate the oxidative damages. Polyamines are one of those moieties which have been reported to encounter a number of abiotic stresses (water deficit, metal toxicity, high illumination), inducing oxidative exposure (Anjum et al. 2011). 
Polyamines are organic polycationic unsaturated hydrocarbon, with two or more primary amino groups. The diamine putrescine, triamine spermidine and tetraamine spermine are widespread in plant system, which are ubiquitous in nature having low molecular weight and straight chain aliphatic amines whose concentration fluctuates from $\mu \mathrm{M}$ to $\mathrm{mM}$ (Roychoudhury et al. 2011). Polyamines are involved in a variety of fundamental cellular processes, including transcription, RNA modification, protein synthesis and the modulation of enzyme activities (Tabor and Tabor 1999). The simplest polyamine like putrescine (Put) is derived either directly from ornithine by ornithine decarboxylase (ODC) or from arginine, following several steps subsequently catalysed by arginine decarboxylase (ADC), agmatine iminohydrolase and N-carbamoyl putrescine amidohydrolase. Put is converted to spermidine and spermine by successive activities of spermidine synthase and spermine synthase, respectively, with the use of decarboxylated S-adenosyl methionine (dcSAM) as an aminopropyl donor (Bagni and Tassoni 2001, Cona et al. 2006, Moschou et al. 2008).

In plants, polyamines are found to be variably distributed in different tissues. A number of physiological regulation in control of cell division, embryogenesis, root formation, fruit ripening, perception of biotic and abiotic stress response is modulated by polyamines (Kumar et al. 1997). Moreover, polyamines have been evident to be effective in up/down expression of physiological activities under abiotic stresses (Alcázar et al. 2010) and polyamine applied exogenously to downregulate the oxidative stress is less frequently studied. On the other hand, $\mathrm{H}_{2} \mathrm{O}_{2}$ is well documented to change the redox potential of the tissues (Basu et al. 2010). Therefore, it could be hypothesized that polyamine could be interacting with cellular redox in tissues of such a way that ROS-induced oxidative damage is minimized. Precise mechanism of such polyamine mediated resistance to oxidative stress is yet to be deciphered. With this background, an experiment has been conducted to induce plant with exogenously applied $\mathrm{H}_{2} \mathrm{O}_{2}$ for developing oxidative stress and to monitor its modulation.

In most of the cases, angiosperms have been implicated in studies about antioxidation pathways under various abiotic stresses (Sánchez-Galván et al. 2008). Non-angiosperm plants, like ferns, are less explored in this regard. Chinese brake fern (Pteris vittata) has been proved to be a hyper accumulator of heavy metals and shows a good tolerance against ROS under oxidative stress (Xie et al. 2009). Salvinia natans is a small aquatic fern with branched creeping stems, bearing hairs but no true roots and are free-floating widely grown in contaminated area or water streams with profuse industrial effluents. These effluents essentially contain different toxic materials, including oxides and hydroxides of heavy metals, which are mainly responsible for high production of $\mathrm{H}_{2} \mathrm{O}_{2}$ in water (Gardner and Al-Hamdani 1997, Prado et al. 2010). Due to high diffusion of $\mathrm{H}_{2} \mathrm{O}_{2}$ in water, those contaminated areas become more toxic and, as a result, plants get affected. Salvinia natans are common habitats of such stringent condition and proved its ability to sustain with its optimum growth (Dhir et al. 2011). Therefore, a possible relationship in regard to polyamine mediated $\mathrm{H}_{2} \mathrm{O}_{2}$ metabolism deserves its worth to be studied. Thus, we propose to study how this fern species could react with $\mathrm{H}_{2} \mathrm{O}_{2}$ induced oxidative stress and modulate their responses with elicitors like polyamine. This study was undertaken to reveal the impact of $\mathrm{H}_{2} \mathrm{O}_{2}$ on Salvinia natans with reference to oxidative stress and its possible interaction with polyamine.

\section{MATERIAL AND METHODS}

Plant material and growth conditions: Salvinia natans (L.), floating aquatics with creeping stems, was taken as the plant material. Plants were collected from unpolluted pond or marshy land. After repeated washing with deionized water, these plants were transferred into Murashige and Skoog media (Murashige and Skoog 1962) and kept in a greenhouse for 7 days at $37 \pm 1^{\circ} \mathrm{C}, 70-80 \%$ of relative humidity and duration of light/dark $14 \mathrm{~h} / 10 \mathrm{~h}$, respectively. After that time, the plants were incubated with varying concentrations of $0,50,100 \mu \mathrm{M}$ of $\mathrm{H}_{2} \mathrm{O}_{2}$ and $100 \mu \mathrm{M}$ of $\mathrm{H}_{2} \mathrm{O}_{2}$ supplemented with $1 \mathrm{mM}$ of Put for $6 \mathrm{~h}$ in a dark chamber (Sairam and Srivastava 2000). Plants in each set of treatments were replicated three times $(n=3)$.

Determination of $\mathrm{H}_{\mathbf{2}} \mathrm{O}_{\mathbf{2}}$ content: The $\mathrm{H}_{2} \mathrm{O}_{2}$ content of the tissue was measured spectrophotometrically (Cecil, Model No. CE7200), according to Loreto and Velikova (2001); $1 \mathrm{~g}$ of fresh sample with three replications for each treatment was homogenized in $3 \mathrm{~mL}$ of trichloroacetic acid (TCA) (1\%) and centrifuged at $10,000 \mathrm{x} g$ for $10 \mathrm{~min}$ at $4^{\circ} \mathrm{C}$ (Hermle, Model No. Z323K). Subsequently, $0.75 \mathrm{~mL}$ of the supernatant was added to the $0.75 \mathrm{~mL}$ of $10 \mathrm{mM}$ phosphate buffer ( $\mathrm{pH} 7.0$ ) containing $1.5 \mathrm{~mL}$ of $1 \mathrm{M} \mathrm{KI}$. The intensity was measured at $390 \mathrm{~nm}$. The $\mathrm{H}_{2} \mathrm{O}_{2}$ content was calculated with molar extinction coefficient $0.28 \mu \mathrm{mol} \mathrm{cm}^{-1}$.

Histochemical detection of $\mathrm{H}_{2} \mathrm{O}_{2}: \mathrm{H}_{2} \mathrm{O}_{2}$ was detected histochemicaly in leaves by using 3,3-diaminobenzidine (DAB) as substrate (Chao et al.2010). In the present experiment, leaf tissue was dipped in DAB ( $\left.1 \mathrm{mg} \mathrm{mL}^{-1}\right)$ solution ( $\left.\mathrm{pH} \mathrm{4}\right)$ through the cut ends of fronds for $8 \mathrm{~h}$ under light at $27^{\circ} \mathrm{C}$. The tissues were then decolorized in boiling ethanol (95\%) for $20 \mathrm{~min}$. 
This treatment decolorized the tissues, except for the brown colored polymerized product produced by $\mathrm{DAB}$ with $\mathrm{H}_{2} \mathrm{O}_{2}$. After cooling, the tissues were observed under light microscope to visualize the brown spots.

Net assimilation rate (NAR): The dry weights were measured before and after incubation in $\mathrm{H}_{2} \mathrm{O}_{2}$ treatments. For both cases, $5 \mathrm{~g}$ of whole plant tissue were taken from each of the treatments and the samples were dried at $80^{\circ} \mathrm{C}$ in an oven to record their dry weights. The NAR was calculated on the basis of dry weights and leaf area of the plants before and after the treatment; it was computed as suggested by Baset Mia and Shamsuddin (2011) and expressed as $\mathrm{g} \mathrm{m}^{-2} \mathrm{~d}^{-1}$.

Lipid peroxidation: For lipid peroxidation in terms of malondialdehyde (MDA) content, $5 \mathrm{~g}$ of leaves from each treatment with three replications were extracted with extraction buffer containing $20 \%(\mathrm{w} / \mathrm{v})$ TCA and $0.5 \%$ thiobarbituric acid (TBA) followed by warming at $95^{\circ} \mathrm{C}$ for $30 \mathrm{~min}$. Reaction was terminated by placing the mixture in ice for $30 \mathrm{~min}$ followed by centrifugation at $12,000 \mathrm{x} g$ for $10 \mathrm{~min}$. The absorbance of the supernatant was read at both 532 and $600 \mathrm{~nm}$. MDA content was derived according to Dhindsa et al. (1981).

Estimation of chlorophyll: The chlorophyll content was estimated according to Ghosh et al. (2011); $5 \mathrm{~g}$ of fresh samples from each treatment with three replications were homogenized thoroughly with $80 \%$ acetone and centrifuged at $4,000 \mathrm{xg}$ for $10 \mathrm{~min}$ at $4^{\circ} \mathrm{C}$. Supernatant was taken as the source of chlorophyll and was measured by reading the absorbance at 645 and $663 \mathrm{~nm}$ with a UV-V Spectrophotometer.

Determination of anthocyanin: Among the major antioxidants, anthocyanin from the treated plants was determined according to Eryilmaz (2006). Leaves from each treatment were crushed in liquid $\mathrm{N}_{2}$ followed by homogenization thoroughly in $80 \%$ methanol- $\mathrm{HCl}(\mathrm{v} / \mathrm{v})$ and the homogenate was incubated for $48 \mathrm{~h}$ at $4^{\circ} \mathrm{C}$. The homogenate was filtered and the filtrate was centrifuged at $1,000 \mathrm{x} g$ for $15 \mathrm{~min}$ at $4^{\circ} \mathrm{C}$. The absorbance was recorded at two different wavelengths and the quantification of anthocyanin was obtained by subtracting the values of absorption in nanometers (i.e. $\left.A_{530}-A_{600}\right)$.

Determination of flavonoids: The samples were crushed in $80 \%$ aqueous ethanol followed by centrifugation at $11,000 \times \mathrm{g}$ for $20 \mathrm{~min}$. The supernatant was added with a reaction mixture containing $5 \%$ sodium nitrite $\left(\mathrm{NaNO}_{2}\right)$ and $10 \%$ aluminium chloride $\left(\mathrm{AlCl}_{3}\right)$. Finally, $1 \mathrm{M} \mathrm{NaOH}$ was added to the reaction mixture and absorption was read at $510 \mathrm{~nm}$. Total flavonoid was determined with a standard solution of quercetin (Sigma) and expressed as $\mu \mathrm{mol} \mathrm{g}{ }^{-1}$ (Ghasemi et al. 2009).

Total phenolics: The fresh leaves were homogenized in $80 \%$ hot ethanol and centrifuged at $10,000 \mathrm{x} g$ for $15 \mathrm{~min}$ at $4^{\circ} \mathrm{C}$ for determination of total phenolics. The supernatant was kept in a water bath to evaporate ethanol and then dissolved in a minimum volume of water. An aliquot of $0.5 \mathrm{~mL}$ was treated with Folin-Ciocalteu reagent followed by addition of $20 \%$ sodium carbonate $\left(\mathrm{Na}_{2} \mathrm{CO}_{3}\right)$. The mixture was incubated in a boiling water bath for $1 \mathrm{~min}$. The intensity of color was recorded at $650 \mathrm{~nm}$ and the phenol content was derived with gallic acid as standard, according to Mohsen and Ammar (2009).

Assay of antioxidative enzyme activity: The assay for antooxidant enzymes of Salvinia natans plants under $\mathrm{H}_{2} \mathrm{O}_{2}$ treatments was monitored by studying the guaiacol peroxidase (GPX), ascorbate peroxidase (APX), catalase (CAT), glutathione reductase (GR) and super oxide dismutase (SOD) following appropriate protocol for extraction, purification and assay reaction (Maiti et al. 2012, Yang et al. 2012). For each type of enzyme, the leaves were crushed in liquid nitrogen followed by homogenization with respective extraction buffer. The enzyme extract was collected following centrifugation and purification. The activity of GPX (EC 1.11.1.7) was assayed spectrophotometrically, according to $\mathrm{Hu}$ et al. (2009), in a reaction mixture containing $0.1 \mathrm{M}$ phosphate buffer, $\mathrm{pH}$ 6.5, 1.5 mM O-dianisidine (electron donor), $0.2 \mathrm{M} \mathrm{H}_{2} \mathrm{O}_{2}$ (substrate) and equivalent amount of enzyme extract containing $50 \mu \mathrm{g}$ of protein. The change of absorbance was read at $430 \mathrm{~nm}$ and the enzyme activity was determined according to Maiti et al. (2012). The activity of APX (EC 1.11.1.11) was assayed in a reaction mixture containing $100 \mathrm{mM}$ phosphate buffer ( $\mathrm{pH} 7.5$ ), $0.5 \mathrm{mM}$ ascorbate and $0.2 \mathrm{mM} \mathrm{H}_{2} \mathrm{O}_{2}$, followed by adding enzyme source of equivalent amount of protein; the absorbance was recorded at $290 \mathrm{~nm}$ (Karuppanapandian et al. 2011). For assay of CAT (E.C. 1.11.1.6), the enzyme extract containing $50 \mu \mathrm{g}$ of protein was incubated in a reaction mixture, which was prepared by $0.5 \mathrm{mM}$ potassium phosphate buffer ( $\mathrm{pH} \mathrm{7)}$ and $10 \mathrm{mM} \mathrm{H}_{2} \mathrm{O}_{2}$. The activity was determined by reading the decreasing absorbance at $240 \mathrm{~nm}$ and was calculated with the extinction coefficient of $\mathrm{H}_{2} \mathrm{O}_{2}$, as suggested by Aebi (1984). Glutathione reductase (GR) (EC 1.6 .4 .2) was assayed in a reaction mixture containing $100 \mathrm{mM} \mathrm{HEPES}$ $\mathrm{KOH}$ buffer ( $\mathrm{pH} 7.5$ ), $10 \mathrm{mM}$ magnesium chloride $\left(\mathrm{MgCl}_{2}\right)$, $0.5 \mathrm{mMmethionine,} 0.5 \mathrm{mMDT}, 0.2 \mathrm{mMNADH}$ and $0.5 \mathrm{mM}$ oxidized glutathione (GSSG). The enzyme extract containing $50 \mu \mathrm{g}$ of enzyme protein was added to the reaction mixture. 


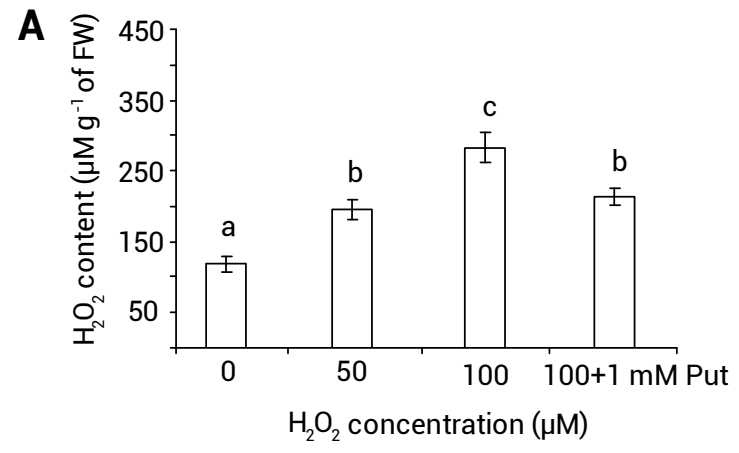

B
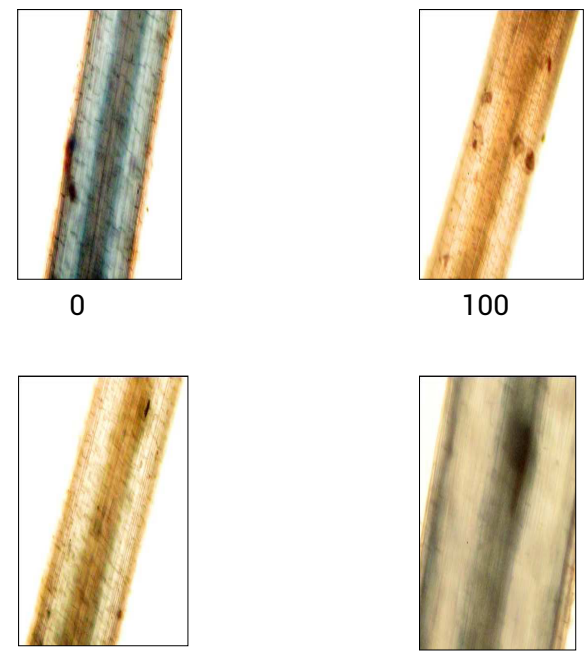

50
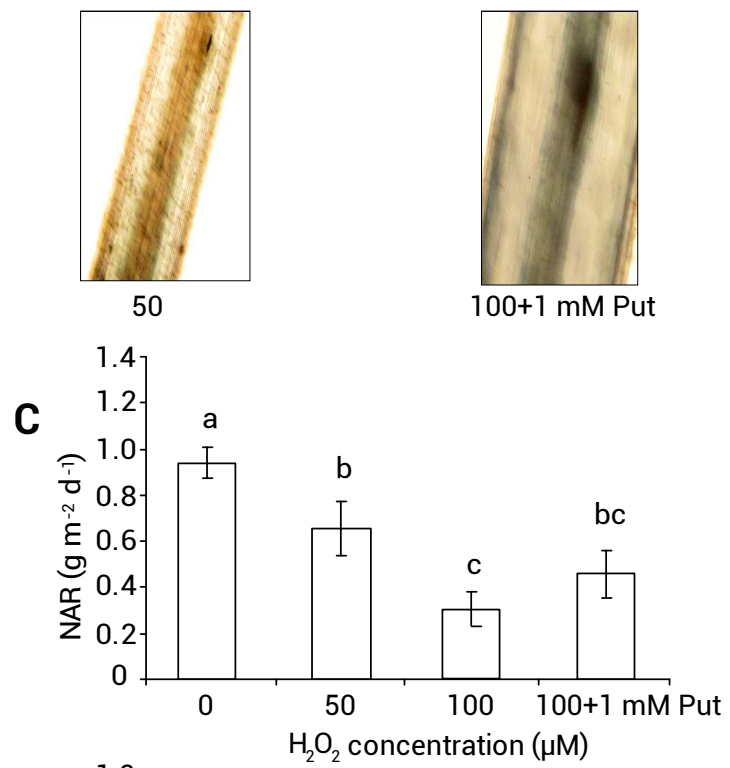

D

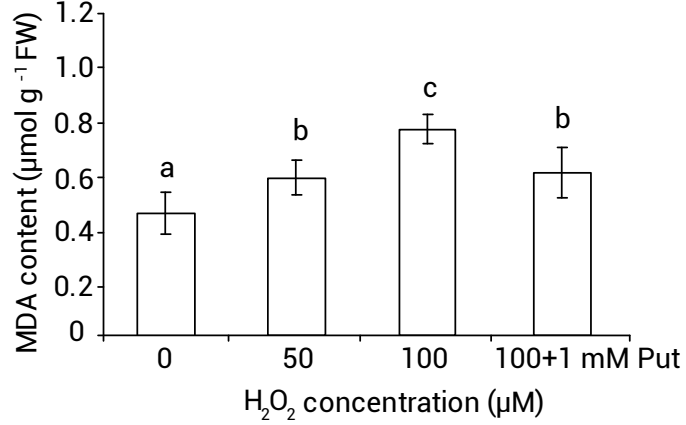

Figure 1. (A) Generation of $\mathrm{H}_{2} \mathrm{O}_{2}$; (B) Tissue analysis by 3,3-diaminobenzidine (DAB) stain; (C) Total net assimilation rate (NAR); (D) Lipid peroxidation (in terms of malondialdehyde - MDA content) of Salvinia natans under different concentrations $(0,50$ and $100 \mu \mathrm{M})$ of $\mathrm{H}_{2} \mathrm{O}_{2}$ treatment and $100 \mu \mathrm{M}$ of $\mathrm{H}_{2} \mathrm{O}_{2}$ supplemented with $1 \mathrm{mM}$ Put after 7 days of culture. The values are plotted in means $( \pm$ Standar error) of replication $(n=3) ; * p \leq 0.05)$.
The activity was recorded from oxidation of $\mathrm{NAD}(\mathrm{P}) \mathrm{H}$ with its extinction coefficient $6.22 \mathrm{mM} \mathrm{cm}^{-1}$. One unit of enzyme was regarded as $\mu \mathrm{M}$ NADPH oxidized $\min ^{-1} \mu \mathrm{g}$ protein ${ }^{-1}$. The activity of SOD (EC 1.15.1.1) was assayed in an assay mixture containing $50 \mathrm{mM}$ sodium phosphate buffer $(\mathrm{pH} \mathrm{7})$, $15 \mathrm{mM}$ methionine, $75 \mu \mathrm{M}$ NBT and $100 \mathrm{mM}$ EDTA and kept under fluorescent light for $10 \mathrm{~min}$, followed by measuring the absorbance at $560 \mathrm{~nm}$.

Statistical analysis: All the observations were recorded with three replications $(n=3)$ and the data were expressed as mean \pm SE. The statistical analysis was performed by one-way analysis of variance (ANOVA), taking $\mathrm{p} \leq 0.05$ as significant.

\section{RESULTS}

Intra and intercellular levels of $\mathrm{H}_{2} \mathrm{O}_{2}$ increased during environmental stresses. From the study of different physiological parameters of Salvinia natans grown under various $\mathrm{H}_{2} \mathrm{O}_{2}$ concentrations, it was visualized that $\mathrm{H}_{2} \mathrm{O}_{2}$ plays a crucial role in various physiological processes. As predicted, Put had also been evident as a modulator for the response of plants under such $\mathrm{H}_{2} \mathrm{O}_{2}$ induced oxidative stress.

The effects of oxidative stress and exogenous Put application on accumulation of $\mathrm{H}_{2} \mathrm{O}_{2}$ content are shown in Figure 1A. Thus, the $\mathrm{H}_{2} \mathrm{O}_{2}$ content was significantly upregulated in proportion with doses of $\mathrm{H}_{2} \mathrm{O}_{2}$. Those were 1.66 and 2.39 fold at 50 and $100 \mu \mathrm{M}$ of $\mathrm{H}_{2} \mathrm{O}_{2}$ treatment, respectively, as compared to control. On the contrary, Put minimized the $\mathrm{H}_{2} \mathrm{O}_{2}$ content by $24.5 \%$ in comparison to the highest concentration of $\mathrm{H}_{2} \mathrm{O}_{2}$ (i.e.100 $\mu \mathrm{M})($ Figure 1A).

At cellular level, the accumulation of $\mathrm{H}_{2} \mathrm{O}_{2}$ was detected by histochemical method when the leaf tissues were stained with DAB (Figure 1B). The tissue analysis showed a significant increase of $\mathrm{H}_{2} \mathrm{O}_{2}$ accumulation with distinct colorization, according to concentration gradient of peroxide. On the contrary, it was less detected in the tissue of the sample treated with Put. Therefore, it clearly suggested that Put had been capable to minimize the $\mathrm{H}_{2} \mathrm{O}_{2}$ accumulation in the leaf tissues.

Plants under varying concentration of $\mathrm{H}_{2} \mathrm{O}_{2}$ showed a significant $(\mathrm{p} \leq 0.05)$ change in growth, which was recorded by their total biomass or dry matter production by means of NAR, which means the capacity of the plant for acquisition of net dry matter over a period of time. It was observed a significant $(p \leq 0.05)$ decline of NAR by 30.34 and $67.79 \%$ over control, whereas Put retrieved 1.51 fold in comparison to the highest concentration of $\mathrm{H}_{2} \mathrm{O}_{2}$ (Figure 1C).

Lipid peroxidation is a reliable cellular trait for establishment of oxidative damages in plant. In the present experiment, plants accumulated a significant $(p \leq 0.05)$ rise of 
MDA as a result of lipid peroxidation excess. It showed 1.28 fold increase in MDA content at $50 \mu \mathrm{M}$ of $\mathrm{H}_{2} \mathrm{O}_{2}$ and 1.68 fold at highest concentration of $\mathrm{H}_{2} \mathrm{O}_{2}$ (i.e.100 $\mu \mathrm{M}$ ) over control. Put was evident to downregulate the $\mathrm{H}_{2} \mathrm{O}_{2}$ content by $20.98 \%$ in comparison to the highest concentration of $\mathrm{H}_{2} \mathrm{O}_{2}$ (Figure 1D).

On the other hand, $\mathrm{H}_{2} \mathrm{O}_{2}$ treatment resulted in the reduction of total chlorophyll content. The loss of chlorophyll in Salvinia natans was eminent with the increase of $\mathrm{H}_{2} \mathrm{O}_{2}$ doses in linear fashion. Thus, it was found that the chlorophyll content was reduced significantly $(\mathrm{p} \leq 0.05)$ by 24.06 and $42.13 \%$ at 50 and $100 \mu \mathrm{M}$ of $\mathrm{H}_{2} \mathrm{O}_{2}$ treatment, respectively, with respect to control. On the contrary, Put alleviated the $\mathrm{H}_{2} \mathrm{O}_{2}$ effect on chlorophyll content by 1.17 fold in comparison to the highest concentration of $\mathrm{H}_{2} \mathrm{O}_{2}$ (Figure 2A).

Anthocyanin content had similar responses like chlorophyll and recorded a diminishing of 30.89 and $56.54 \%$ at 50 and $100 \mu \mathrm{M}$ concentration of $\mathrm{H}_{2} \mathrm{O}_{2}$, respectively, in comparison to control. On the other hand, Put retrieved 1.506 fold of anthocyanin content as compared to highest concentration of $\mathrm{H}_{2} \mathrm{O}_{2}$ treatment (Figure $2 \mathrm{~B}$ ). In addition, the plants were induced to accumulate flavonoids under exogenous application of $\mathrm{H}_{2} \mathrm{O}_{2}$. The flavonoid content was significantly upregulated $(\mathrm{p} \leq 0.05)$ and it was 1.12 and 1.31 fold under treatments of $\mathrm{H}_{2} \mathrm{O}_{2}$ (i.e. 50 and $100 \mu \mathrm{M}$, respectively). Put minimized the flavonoid content by $11.3 \%$, as compared to $\mathrm{H}_{2} \mathrm{O}_{2}$ alone (Figure 2C). An increase in total phenolics with $\mathrm{H}_{2} \mathrm{O}_{2}$ concentration was another interesting observation in the plants' response. A consistent trend in phenol accumulation was significantly $(\mathrm{p} \leq 0.05)$ recorded as 1.32 and 1.51 fold at 50 and $100 \mu \mathrm{M}$ of $\mathrm{H}_{2} \mathrm{O}_{2}$ treatments, respectively, as compared to control. On the contrary, Put reduced the phenolic amount by $15.46 \%$ in comparison to the highest concentration of $\mathrm{H}_{2} \mathrm{O}_{2}$ (Figure 2D).

Antioxidative enzymes: Responses to stress are maximally manifested into expression of antioxidative enzymes. In the present experiment, $\mathrm{H}_{2} \mathrm{O}_{2}$, being itself a potent reactive oxygen species, could have been able to induce some of the important antioxidative enzymes. A significant role in SOD, GPX, APX, CAT and GR activity had revealed some interesting results. The activity of antioxidizing enzymes like SOD was significantly $(\mathrm{p} \leq 0.05)$ altered under $\mathrm{H}_{2} \mathrm{O}_{2}$ treatments in a dose dependent manner. It was observed 1.23 and 1.54 fold at 50 and $100 \mu \mathrm{M}$ of $\mathrm{H}_{2} \mathrm{O}_{2}$ treatment, respectively, over control. Interestingly, the application of Put had minimized the activity by $12.89 \%$ in comparison to the highest concentration of $\mathrm{H}_{2} \mathrm{O}_{2}$ (Figure 3A).

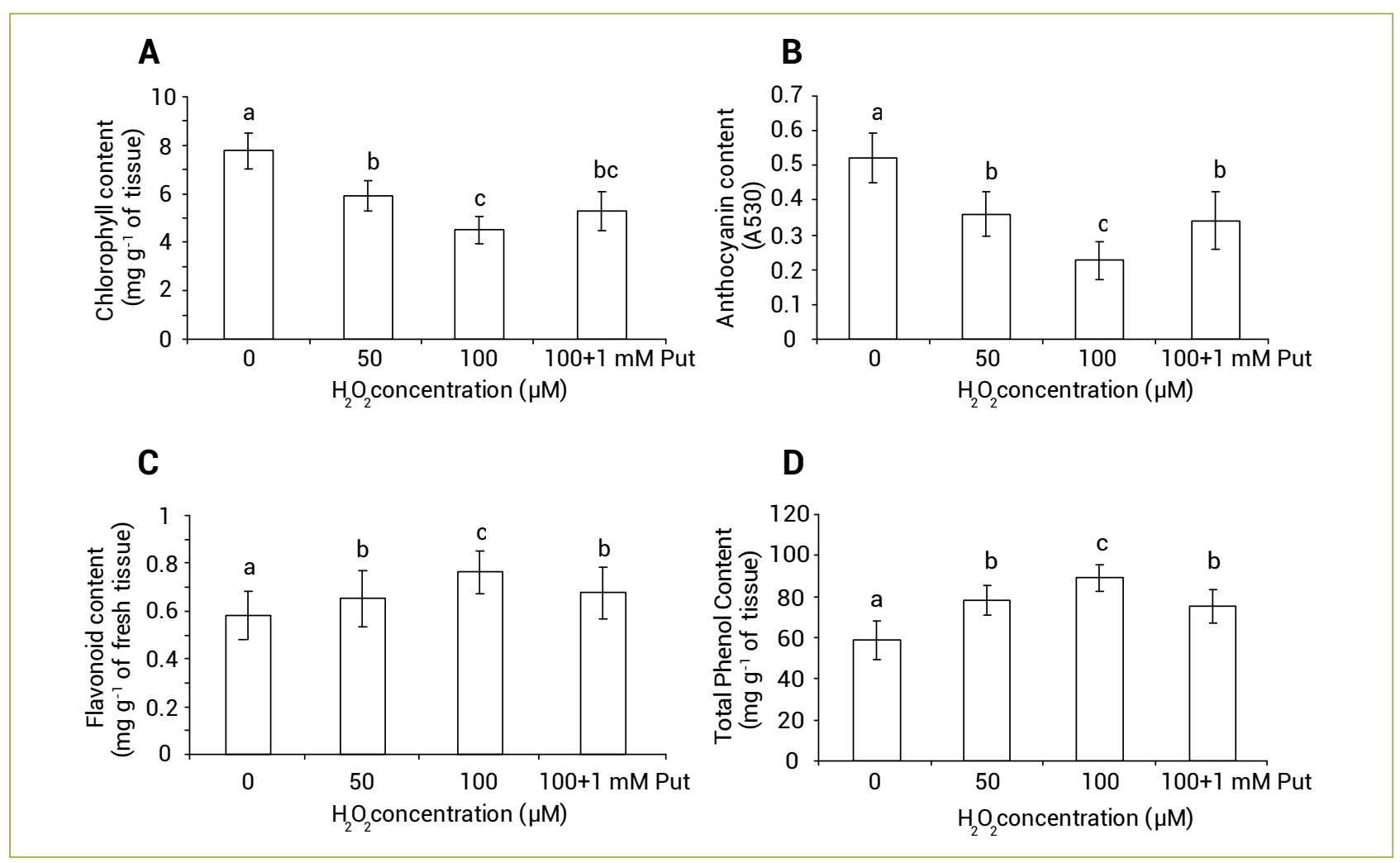

Figure 2. (A) Total chlorophyll content; (B) Anthocyanin content; (C) Flavonoid content; (D) Total phenol content of Salvinia natans under different concentrations $(0,50$ and $100 \mu \mathrm{M})$ of $\mathrm{H}_{2} \mathrm{O}_{2}$ treatment and $100 \mu \mathrm{M}$ of $\mathrm{H}_{2} \mathrm{O}_{2}$ supplemented with 1 mM Put after 7 days of culture. The values are plotted in means $( \pm$ Standard error) of replication $(n=3) ; * 00.05$. 
The in vitro activity of GPX was significantly ( $\mathrm{p} \leq 0.05)$ responsive under $\mathrm{H}_{2} \mathrm{O}_{2}$ treatment in a dose dependent manner. It was observed 1.26 and 1.54 fold in 50 and $100 \mu \mathrm{M} \mathrm{H}_{2} \mathrm{O}_{2}$ treatments, respectively, in comparison to control. On the other hand, Put treatment minimized the activity of GPX by $17.56 \%$ when compared to $100 \mu \mathrm{M}$ of $\mathrm{H}_{2} \mathrm{O}_{2}$ treatment (Figure 3B).

The variation in activity of APX was also dose dependent ( $\mathrm{p} \leq 0.05)$, in which 1.25 and 1.53 fold at 50 and $100 \mu \mathrm{M}$ of $\mathrm{H}_{2} \mathrm{O}_{2}$ treatments were observed, respectively, over control. The application of Put reduced the activity by $14.78 \%$ in comparison to the highest concentration of $\mathrm{H}_{2} \mathrm{O}_{2}$ (i.e.100 $\mu \mathrm{M}$ ) (Figure 3C).
On the other hand, CAT activity showed a different pattern as it was decreased by 19.94 and $34.23 \%$ under 50 and $100 \mu \mathrm{M}$ of $\mathrm{H}_{2} \mathrm{O}_{2}$ treatments, respectively, over control. In addition, Put modulated the enzyme activity and recorded 1.22 fold higher over $100 \mu \mathrm{M}$ of $\mathrm{H}_{2} \mathrm{O}_{2}$ treatment (Figure 3D).

Another antioxidative enzyme, which is required for the steady maintenance of glutathione level, is GR. It showed an increasing tendency, which recorded 1.28 and 1.65 fold at 50 and $100 \mu \mathrm{M}$ of $\mathrm{H}_{2} \mathrm{O}_{2}$ treatments, respectively, over control. Put treatment decreased the GR activity (Unit $\mu \mathrm{g}$ protein ${ }^{-1} \mathrm{~min}^{-1}$ ) by $19.04 \%$ in comparison to the highest concentration of $\mathrm{H}_{2} \mathrm{O}_{2}$ (Figure 3E).

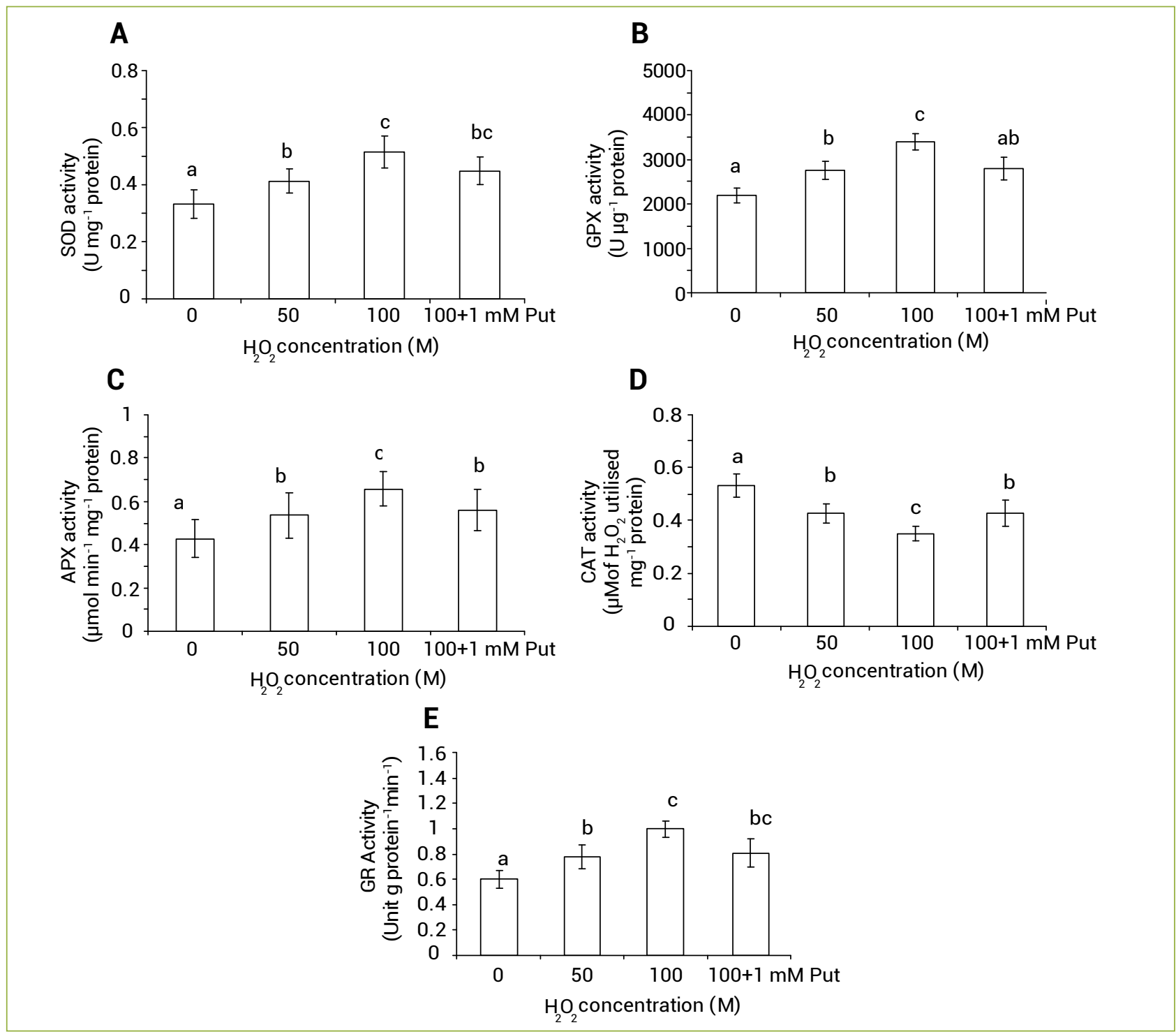

Figure 3. Enzyme activities. (A) Superoxide dismutase (SOD); (B) Guaiacol peroxidase (GPX); (C) Ascorbate peroxidase (APX); (D) Catalase (CAT); (E) Glutathione reductase (GR) of Salvinia natans under different concentrations $(0,50$ and $100 \mu \mathrm{M})$ of $\mathrm{H}_{2} \mathrm{O}_{2}$ treatment and $100 \mu \mathrm{M}$ of $\mathrm{H}_{2} \mathrm{O}_{2}$ supplemented with $1 \mathrm{mM}$ Put after 7 days of culture. The values are plotted in means $( \pm$ Standard error) of replication $(n=3) ; * p \leq 0.05$. 


\section{DISCUSSION}

$\mathrm{H}_{2} \mathrm{O}_{2}$ is not considered a free radical like $\mathrm{O}_{2}^{-}$and $\mathrm{OH}^{-}$. Moreover, with respect to oxidative stress, the threshold value of $\mathrm{H}_{2} \mathrm{O}_{2}$ at the cellular level is considered an indirect stressor for the establishment of the oxidative damage (Sairam and Saxena 2000). In the present case, Salvinia natans recorded distinct features of oxidative damage of cellular metabolites. Thus, chlorophyll content was reduced under $\mathrm{H}_{2} \mathrm{O}_{2}$ treatments in a proportionate manner. In plants, one of the established traits for oxidative damages is the lipid peroxidation, expressed in terms of MDA content. The accumulation of MDA content in Salvinia plants in the present experiment is not an exception. With the increasing concentration of $\mathrm{H}_{2} \mathrm{O}_{2}$, the plants exhibited an upregulated oxidation state in the tissues. For various plant species under oxidative stress, a significant loss of chlorophyll and increase of lipid peroxidation are observed (Alcázar et al. 2010). In spite of this, the reduction in chlorophyll content either through its diminished biosynthetic pathway or oxidation is still to be understood (Panda 2001, Panda and Khan 2009). The decline of photosynthesis through changes in chlorophyll fluorescence and other related phenomena have also been reported in other species of Salvinia under heavy metal stress (Dhir et al. 2008). Interestingly, both chlorophyll and lipid peroxidation in Salvinia natans exhibited an interactive benefit response with the Put application in the present experiment, as it was effective to downregulate the lipid peroxidation and upregulate chlorophyll content.

Polyamines like spermidine, spermine and cadaverine act as alleviators of the oxidative stress in other plant species like Oryza sativa, Triticum aestivum, Arabidopsis thaliana and Atropa belladona (Roy et al. 2005). At the cellular level, polyamine could mitigate the lipid peroxidation by downregulating the $\mathrm{NAD}(\mathrm{P}) \mathrm{H}$-oxidase/NAD $(\mathrm{P}) \mathrm{H}$ peroxidase activity (Gill and Tuteja 2010). $\mathrm{NAD}(\mathrm{P}) \mathrm{H}$ oxidase is regarded as a potential source of $\mathrm{O}_{2}^{-}$and $\mathrm{H}_{2} \mathrm{O}_{2}$ generation, thus causing oxidative injuries in plant tissues (Sharma et al. 2012). In the present experiment, a significant increase in $\mathrm{H}_{2} \mathrm{O}_{2}$ content might be an indirect indication of the $\mathrm{NAD}(\mathrm{P}) \mathrm{H}$-oxidase activity as the accumulation of $\mathrm{H}_{2} \mathrm{O}_{2}$ in the tissues of the Salvinia natans was observed with $\mathrm{DAB}$ staining. Put reduced the $\mathrm{H}_{2} \mathrm{O}_{2}$ accumulation in the affected tissue that was clearly observed through the changes in the $\mathrm{DAB}$ staining.

Plants cope with oxidative stress with the implementation of antioxidative pathways by enzymatic and non-enzymatic attributes (Mandal et al. 2013). Among non-enzymatic attributes, different secondary metabolites are involved in quenching the energy of ROS (Karuppanapandian et al. 2011). Salvinia natans exhibited an elevation of flavonoids and total phenolics with respect to $\mathrm{H}_{2} \mathrm{O}_{2}$ concentration. The activation and increase of phenolics become correlated as a useful trait for plants under oxidative stress (Ghosh et al. 2011). The higher activity of these major antioxidants supposedly renders the Salvinia natans to minimize the $\mathrm{H}_{2} \mathrm{O}_{2}$ induced damages. For instance, flavonoids are considered as a low molecular weight antioxidant that could potentially scavenge the ROS and free radical activity to escape the lipid peroxidation (Basu et al. 2010). Thus, anthocyanin and phenolics are two antioxidants found to be potential agents in scavenging activity of ROS. However, anthocyanin recorded a declining trend according to increasing concentration of $\mathrm{H}_{2} \mathrm{O}_{2}$. In respect to non-enzymatic antioxidation in Salvinia natans, as recorded in the present investigation, Put modulated for changes in concentrations of flavonoids and anthocyanin in the tissue treated with $\mathrm{H}_{2} \mathrm{O}_{2}$. Similar observation was also recorded in other plants under condition inducing oxidative stress (Roychoudhury et al. 2012). Thus, oxidative stress is characterized by abundance of phenolics in many plant species, which might be useful as an index for adaptive nature of plants. Polyamine has effectively supplemented in dose dependent manner in interaction of phenolics in quenching of ROS, as reported earlier (Farooq et al. 2009). Simultaneously, plants are able to cope with the oxidative damages by using some enzymatic pathways, either hydrolyzing the ROS to a state of lower energy or downregulating its biosynthesis. Within the cellular threshold, $\mathrm{H}_{2} \mathrm{O}_{2}$ can act as an intercellular messenger to induce some enzymes like SOD, GPX, APX, CAT, GR etc. (Shah and Nahakpam 2012, Mandal et al. 2013). Salvinia natans exhibited a concomitant activation of those enzymes according to $\mathrm{H}_{2} \mathrm{O}_{2}$ exposure as well as under supplementation with Put. SOD, GPX, APX and GR were significantly upregulated with $\mathrm{H}_{2} \mathrm{O}_{2}$ treatment whereas CAT showed a considerable deactivation. SOD undertakes an irreversible conversion of superoxide $\left(\mathrm{O}_{2}^{-}\right)$into $\mathrm{H}_{2} \mathrm{O}_{2}$, which, in turn, is reduced into $\mathrm{H}_{2} \mathrm{O}$ and $\mathrm{O}_{2}$ by various phenolics as electron donors (Upadhyaya et al. 2007).

Plants can induce a number of peroxidases in different cellular compartments (Achary et al. 2012). Thus, peroxidase, apart from lysis of $\mathrm{H}_{2} \mathrm{O}_{2}$, can induce the polymerization of phenolic residues in the cell wall, i.e. in the process of lignification reaction, $\mathrm{OH}^{-}$and other free radicals act as a conjugant of phenolic monomers. Peroxidases like GPX and APX require guaiacol and ascorbate as their electron donors, respectively. In the present investigation, their activities were induced under $\mathrm{H}_{2} \mathrm{O}_{2}$ treatment and thereafter diminished by application of Put. In general, plants contain a pool of peroxidases that are expressed according to the tissue specificity and even with the stress intensity, in discriminating manner. Any change or deviation of antioxidative enzymes may 
perturb the cellular redox of plants under abiotic stresses (Gill and Tuteja 2010). Therefore, the deactivation of CAT under $\mathrm{H}_{2} \mathrm{O}_{2}$ treatment is deviating from the tendency of upregulating the antioxidative enzymes, as recorded in present experiment with Salvinia natans. In fact, a significant decline in CAT activity was also reported in other plants like angiosperms (Ghosh et al. 2012). The deactivation of the CAT by abiotic stresses might be understood as either retardation of enzyme synthesis or its inactivation (Roychoudhury et al. 2011). Irrespective of the cases, it could be ascertained as a shortfall to lysis of $\mathrm{H}_{2} \mathrm{O}_{2}$ by the enzyme. The other possibility may arise from the fact that cellular level of $\mathrm{H}_{2} \mathrm{O}_{2}$ could be toxic enough to inhibit CAT activity (Basu et al. 2010). Salvinia natans could be able to retrieve the CAT activity by application of Put. Probably, Put might have diminished the $\mathrm{H}_{2} \mathrm{O}_{2}$ impact that could interfere with CAT activity (Shah and Nahakpam 2011).

The changes in GR activity under $\mathrm{H}_{2} \mathrm{O}_{2}$ treatment and its modulation by Put are indicative of the altered oxidative status in the tissues of Salvinia natans. The increase in GR along with $\mathrm{H}_{2} \mathrm{O}_{2}$ exposure thus indicates the recycling of GSH (reduced form) from GSSG (oxidized form)

\section{REFERENCES}

Achary VMM, Patnaik AR, Panda BB (2012) Oxidative biomarkers in leaf tissue of barley seedlings in response to aluminium stress. Ecotoxicology and Environmental Safety 75:16-26.

Aebi H (1984) Catalase in vitro. Methods in Enzymology 105:121-126.

Alcázar R, Altabella T, Marco F, Bortolotti C, Reymond M, Koncz C, et al (2010) Polyamines: molecules with regulatory functions in plant abiotic stress tolerance. Planta 231:1237-1249.

Anjum SA, Xie X, Wang L, Saleem MF, Man C, Lei W (2011) Morphological, physiological and biochemical responses of plants to drought stress. African Journal of Agricultural Research 6:2026-2032.

Bagni N, Tassoni A (2001) Biosynthesis, oxidation and conjugation of aliphatic polyamines in higher plants. Amino Acids 20:301-317.

Baset Mia MA, Shamsuddin ZH (2011) Physio-morphological appraisal of aromatic fine rice (Oryza sativa L.) in relation to yield potential. International Journal of Botany 7:223-229.

Basu S, Roychowdhury A, Saha P, Sengupta DN (2010) Differential antioxidative responses of indica rice cultivars to drought stress. Plant Growth Regulation 60:51-59. state. It is also reported that GSH is more effective in maintaining the adequate oxidation state in plants under oxidative stress (Ghosh et al. 2012). GSH, on the other hand, could supplement the ascorbate from its dehydrated state as a substrate for ascorbate peroxidase. Therefore, the complementation of glutathione and ascorbate is essential for maintaining the cellular equilibrium under stress conditions. Similar tendency has also been interpreted in other plant species where involvement of GR becomes a sensible trait for assessing the oxidative stress (Ding et al. 2012).

Conclusively, the results of the present investigation clearly reveal the cellular responses of Salvinia natans under $\mathrm{H}_{2} \mathrm{O}_{2}$ induced oxidative stress resulting in various physiological, enzymatic and non-enzymatic changes. Put is effectively capable to mitigate those oxidative damages. Salvinia natans, being a non-angiosperm, pteridophytic plant species, is found to interact with polyamine at cellular level as revealed by the present experiment.

\section{ACKNOWLEDGMENTS}

This work was financially supported by DST-PURSE program, India.

Becana M, Moran JF, Iturbe-Ormaetxe I (1998) Iron-dependent oxygen free radical generation in plants subjected to environmental stress: toxicity and antioxidant protection. Plant and Soil 201:137-147.

Chao YY, Chen CY, Huang WD, Kao CH (2010) Salicylic acidmediated hydrogen peroxide accumulation and protection against Cd toxicity in rice leaves. Plant and Soil 329:327-337.

Cheeseman JM (2007) Hydrogen peroxide and plant stress: a challenging relationship. Plant Stress 1:4-15.

Cona A, Rea G, Angelini R, Federico R, Tavladoraki P (2006) Functions of amine oxidases in plant development and defence. Trends in Plant Science 11:80-88.

Dhindsa RS, Plumb-Dhindsa P, Thorpe TA (1981) Leaf senescence: correlated with increased levels of membrane permeability and lipid peroxidation, and decreased levels of superoxide dismutase and catalase. Journal of Experimental Botany 32:93-101.

Dhir B, Sharmila P, Pardha Saradhi P (2008) Photosynthetic performance of Salvinia natans exposed to chromium and zinc rich wastewater. Brazilian Journal of Plant Physiology 20:61-70.

Dhir B, Sharmila P, Pardha Saradhi P, Sharma S, Kumar R, Mehta D (2011) Heavy metal induced physiological alterations in Salvinia natans. Ecotoxicology and Environmental Safety 74:1678-1684. 
Ding S, Lei M, Lu Q, Zhang A, Yin Y, Wen X, et al (2012) Enhanced sensitivity and characterization of photosystem II in transgenic tobacco plants with decreased chloroplast glutathione reductase under chilling stress. Biochimica et Biophysica Acta 1817:1979-1991.

Eryılmaz F (2006) The relationships between salt stress and anthocyanin content in higher plants. Biotechnology \& Biotechnological Equipment 20:47-52.

Farooq M, Wahid A, Kobayashi N, Fujita D, Basra SMA (2009) Plant drought stress: effects, mechanisms and management. Agronomy for Sustainable Development 29:185-212.

Gardner JL, Al-Hamdani S (1997) Interactive effects of aluminum and humic substances on Salvinia. Journal of Aquatic Plant Management 35:30-34.

Ghasemi K, Ghasemi Y, Ebrahimzadeh MA (2009) Antioxidant activity, phenol and flavonoid contents of 13 citrus species peels and tissues. Pakistan Journal of Pharmaceutical Sciences 22:277-281.

Ghosh N, Adak MK, Ghosh PD, Gupta S, Sengupta DN, Mandal C (2011) Differential responses of two rice varieties to salt stress. Plant Biotechnology Reports 5:89-103.

Ghosh N, Das SP, Mandal C, Gupta S, Das K, Dey N, et al (2012) Variations of antioxidative responses in two rice cultivars with polyamine treatment under salinity stress. Physiology and Molecular Biology of Plants 18:301-313.

Gill SS, Tuteja N (2010) Reactive oxygen species and antioxidant machinery in abiotic stress tolerance in crop plants. Plant Physiology and Biochemistry 48:909-930.

Hu Y, Ge Y, Zang C, Zu T, Cheng W (2009) Cd toxicity and translocation in rice seedlings are reduced by hydrogen peroxide treatments. Plant Growth Regulation 59:51-61.

Karuppanapandian T, Moon JC, Kim C, Manoharan K, Kim W (2011) Reactive oxygen species in plants: their generation, signal transduction, and scavenging mechanisms. Australian Journal of Crop Science 5:709-725.

Kumar A, Altabella T, Taylor MA, Tiburcio AF (1997) Recent advances in polyamine research. Trends in Plant Science 2:124-130.

Loreto F, Velikova V (2001) Isoprene produced by leaves protects the photosynthetic apparatus against ozone damage, quenches ozone products, and reduces lipid peroxidation of cellular membranes. Plant Physiology 127:1781-1787.

Maiti S, Ghosh N, Mandal C, Das K, Dey N, Adak MK (2012) Responses of the maize plant to chromium stress with reference to antioxidation activity. Brazilian Journal of Plant Physiology 24:203-212.

Mandal C, Ghosh N, Maiti S, Das K, Gupta S, Dey N, et al (2013) Antioxidative responses of Salvinia (Salvinia natans Linn.) to aluminium stress and it's modulation by polyamine. Physiology and Molecular Biology of Plants 19:91-103.

Mohsen S, Ammar ASM (2009) Total phenolic contents and antioxidant activity of corn tassel extracts. Food Chemistry 112:595-598.
Moschou PN, Paschalidis KA, Roubelakis-Angelakis KA (2008) Plant polyamine catabolism: the state of the art. Plant Signaling \& Behavior 3:1061-1066.

Murashige T, Skoog F (1962) A revised medium for rapid growth and bio assays with tobacco tissue cultures. Physiologia Plantarum 15:473-497.

Nathues E, Joshi S, Tenberge KB, von den Driesch M, Oeser $\mathrm{B}$, Bäumer $\mathrm{N}$, et al (2004) CPTF1, a CREB-like transcription factor, is involved in the oxidative stress response in the phytopathogen Claviceps purpurea and modulates ROS level in its host Secale cereale. Molecular Plant-Microbe Interactions 17:383-93.

Panda SK (2001) The biology of oxidative stress in green cells: a review. In: Panda SK. Advances in Stress Physiology of Plants. India: Scientific Publishers. pp.1-13.

Panda SK, Khan MH (2009) Growth, oxidative damage and antioxidant responses in greengram (Vigna radiata L.) under short-term salinity stress and its recovery. Journal of Agronomy and Crop Science 195:442-454.

Prado C, Rodríguez-Montelongo L, González JA, Pagano EA, Hilal M, Prado FE (2010) Uptake of chromium by Salvinia minima: effect on plant growth, leaf respiration and carbohydrate metabolism. Journal of Hazardous Materials 177:546-553.

Roy PK, Niyogi K, SenGupta DN, Ghosh B (2005) Spermidine treatment to rice seedlings recovers salinity stress-induced damage of plasma membrane and PM-bound $\mathrm{H}^{+}$-ATPase in salt-tolerant and salt-sensitive rice cultivars. Plant Science 168:583-591.

Roychoudhury A, Basu S, Sengupta DN (2011) Amelioration of salinity stress by exogenously applied spermidine or spermine in three varieties of indica rice differing in their level of salt tolerance. Journal of Plant Physiology 168:317-328.

Roychoudhury A, Basu S, Sengupta DN (2012) Antioxidants and stress-related metabolites in the seedlings of two indica rice varieties exposed to cadmium chloride toxicity. Acta Physiologiae Plantarum 34:835-847.

Sairam RK, Saxena DC (2000) Oxidative stress and antioxidants in wheat genotypes: possible mechanism of water stress tolerance. Journal of Agronomy and Crop Science 184:55-61.

Sairam RK, Srivastava GC (2000) Induction of oxidative stress and antioxidant activity by hydrogen peroxide treatment in tolerant and susceptible wheat genotypes. Biologia Plantarum 43:381-386.

Sánchez-Galván G, Monroy O, Gómez J, Olguín EJ (2008) Assessment of the hyperaccumulating lead capacity of Salvinia minima using bioadsorption and intracellular accumulation factors. Water, Air, \& Soil Pollution 194:77-90.

Shah K, Nahakpam S (2012) Heat exposure alters the expression of SOD, POD, APX and CAT isozymes and mitigates low cadmium toxicity in seedlings of sensitive and tolerant rice cultivars. Plant Physiology and Biochemistry 57:106-113. 
Shah K, Nahakpam S (2011) Heat stress and cadmium toxicity in higher plants: an overview. In: Hemantranjan A. Advances in Plant Physiology. Jodhpur: Scientific Publishers. pp.243-280.

Sharma P, Jha AB, Dubey RS, Pessarakli M (2012) Reactive oxygen species, oxidative damage, and antioxidative defense mechanism in plants under stressful conditions. Journal of Botany 2012:1-26.

Tabor CW, Tabor H (1999) It all started on a streetcar in Boston. Annual Review of Biochemistry 68:1-32.
Upadhyaya H, Khan MH, Panda SK (2007) Hydrogen peroxide induces oxidative stress in detached leaves of Oryza sativa L. General and Applied Plant Physiology 33:83-95.

Xie QE, Yan XL, Liao XY, Li X (2009) The Arsenic Hyperaccumulator Fern Pteris vittata L. Environmental Science \& Technology 43:8488-8495.

Yang ZB, Eticha D, Albacete A, Rao IM, Roitsch T, Horst WJ (2012) Physiological and molecular analysis of the interaction between aluminium toxicity and drought stress in common bean (Phaseolus vulgaris). Journal of Experimental Botany 63:3109-3125. 